institution, which will quickly develop a research potential as students are attracted to York for higher degrees in Southern African Studies and as the research material available in the library expands. The Politics Department started a B.Phil. in Southern African Politics in October 1971 ; it is hoped to start similar postgraduate degrees in other disciplines in October 1973. Modern archives are being collected and a number of generous gifts have already been made or promised, of which the most important is the records of the Capricorn Africa Society. It is hoped that in due course the Centre will be able to offer visiting Fellowships (and a neutral meeting ground) to scholars from all parts of Southern Africa.

\title{
Colloque International sur les Méthodes d'Enquête et de Description des Langues sans Tradition Ecrite: Nice, juin-juillet 1971.
}

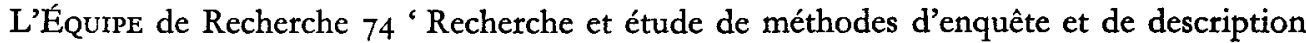
des langues sans écriture avec application aux langues des plateaux d'Afrique Centrale' du Centre National de la Recherche Scientifique, a organisé, du 28 juin au 2 juillet 197 r, un colloque international sur les méthodes d'enquête et de description des langues sans tradition écrite, sous la présidence de Jacqueline Thomas et de Gabriel Manessy.

La nécessité de disposer au départ de questionnaires d'enquête rédigés dans une saine perspective méthodologique s'est fait sentir chez un grand nombre de chercheurs, non seulement dans le domaine de la linguistique, mais aussi dans des domaines connexes (ethno-botanique, -zoologie, -musicologie, -technologie). D'autre part, il serait souhaitable, principalement pour les besoins de la comparaison, de posséder des descriptions d'un grand nombre de langues, rédigées suivant des principes et, si possible, suivant un modèle identique.

Le colloque avait été préparé pendant plus de quinze mois et les grandes lignes en avaient été abordées au cours des séminaires bi-mensuels de l'Er 74 .

Les principaux thèmes abordés s'inscrivent dans les rubriques suivantes:

I. Préliminaires à l'enquête. Élaboration des questionnaires.

2. Techniques d'information.

3. Problèmes de comparaison généalogique.

4. Constitution des corpus et méthodes de description.

5. Organisation et fonctionnement des équipes de recherche. Programmes et travaux en cours.

Une trentaine de participants, originaires de onze pays différents, ont présenté des communications, dont la plupart se référaient à des langues d'Afrique Noire. Leur publication interviendra dans le courant de l'année 1972 et comprendra, outre le texte de celles-ci, les interventions des participants, les rapports des présidents de séance et une préface des organisateurs, J. Thomas et $G$. Manessy.

A l'occasion de ce colloque, l'Er 74 a publié un ouvrage collectif constitué de cinq fascicules rangés en un coffret de $21 \times 27 \mathrm{~cm}$. L'ensemble, couvrant 750 pages et illustré de nombreuses figures, est intitulé: Enquête et Description des langues à tradition orale. Ce manuel du linguiste de terrain comprend:

I. Introduction, qui se distribue elle-même en deux volets : I. l'enquête de terrain; 2. les notions d'analyse grammaticale pour la description.

II. Questionnaires grammaticaux (de l'enquête extensive aux types d'énoncés, en passant par la phonologie, la morphologie, les phénomènes de dérivation et de composition, le syntagme verbal et le syntagme nominal); l'ensemble est précédé d'instructions d'enregistrement.

III. Questionnaire de 6400 phrases qui constitue une exploitation du lexique de la langue étudiće à partir du français. 
IV. Questionnaire des techniques, qui vise à permettre au linguiste de recueillir rapidement un vocabulaire important concernant les techniques, plus particulièrement celles d'Afrique Centrale.

V. Questionnaires thématiques: noms de plantes, noms d'animaux, l'anatomie et la physiologie animales et végétales; les phénomènes sociologiques (organisation familiale, politique et sociale, tableaux de parenté) et psychologiques avec en annexe des questionnaires sur les noms de personnes, de lignages et d'animaux domestiques; tradition orale: recueil de textes et ethnomusicologie; contacts de langues.

Ce volume est en vente à la SELAF (Société pour l'Étude des Langues Africaines), également siège de la revue Bibliothèque de la SELAF, s, rue de Marseille, 750 ro Paris, qui publiera également les Actes du Colloque.

J. Thomas

\section{Mrs. Melville J. Herskovits}

Members of the Institute will learn with regret that Mrs. Frances Herskovits, widow of the distinguished anthropologist and founder of the Program of African Studies at Northwestern University, died on 4 May 1972. Mrs. Herskovits, who with her husband had been closely associated with Northwestern since 1927, was active in the research which he conducted during his extensive study tours including his major research on Dahomey. After her husband's death in 1963 , she continued many of the projects begun by him and edited much of his unpublished work. The Herskovits papers are part of the outstanding Africana library collection in Northwestern's University Library, where the Melville J. Herskovits Library of African Studies is one of the most varied and comprehensive Africana collections in the United States.

\section{The Preservation of Nigerian Antiquities}

A WEEK-END symposium on the preservation of Nigerian antiquities was held at the Institute of African Studies of the University of Ibadan in April 1972. Those taking part included representatives and staff of African studies, archaeology, and history departments of the universities, the Antiquities Department, the Nigerian Antiquities Commission, the Nigerian police, and the customs department. The Chairman of the Antiquities Commission, Professor S. O. Biobaku, delivered the opening address, and Mr. Bayo Akinnola, Western State Commissioner for Information and Home Affairs, inaugurated the symposium and the small but representative exhibition of antiquities arranged for its duration. Papers touching on many different aspects of the problem were presented and discussion groups were formed, focusing on three main topics: the problem of preservation of antiquities within Nigeria; the creation of institutions for the legal sale of works of art; the prevention of illegal export of antiquities. Papers were presented on antiquities in Igboland, Yorubaland, Kwara, the North-western and North-central states, but very little information was contributed on groups such as the Efik and Ibibio and the peoples of the North-eastern State. It was pointed out that many antiquities are destroyed by religious iconoclastsChristian and Muslim-and by modern developments in the towns. Physical deterioration from natural causes as well as the decline of traditional religious worship also accounts for the disappearance of many valuable objects.

Recommendations arising out of group discussions were presented to the final plenary session. Attention was focused on certain areas which are of immediate concern and it was felt that the Antiquities Ordinance of 1953 needed to be revised to give greater protection. The greatest emphasis, however, both in the discussions and the recommendations was on mass education at school and post-school levels to stimulate and develop respect for 